\title{
Physiological responses of photosynthesis in black pepper plants under different shade levels promoted by intercropping with rubber trees
}

\section{Respostas fisiológicas da fotossíntese em plantas de pimenta do reino sob diferentes níveis de sombreamento promovidos por consorcio com seringueiras}

\author{
Marcos Góes Oliveira', Gleison Oliosi', Fábio Luiz Partelli", José Cochicho Ramalho²
}

\author{
'Universidade Federal do Espírito Santo/UFES, Departamento Ciências Agrárias e Biológicas/DCAB, São Mateus, ES, Brasil \\ 2Universidade de Lisboa/ULisboa, Departamento Recursos Naturais, Ambiente e Território/DRAT, Oeiras, Portugal \\ *Corresponding author: partelli@yahoo.com.br \\ Received in September 3, 2018 and approved in October 11, 2018
}

\begin{abstract}
Plants of black pepper (Piper nigrum L.) may display changes in their photosynthetic activity as a result of environmental seasonal changes. Intercropping with tree species may represent an alternative to mitigate the impacts of climatic changes on crops. The objective of this work was to evaluate the physiological responses of photosynthesis in black pepper plants under different shade levels promoted by intercropping with rubber trees (Hevea brasiliensis (Willd. ex A. Juss.) Müll. Arg. The photosynthetic performance in black pepper along the day was evaluated under full sun and five shade levels. The resulted showed that variations positives in leaf gas exchanges were not exclusively dependent on the shade promoted by the distance in relation with the line of rubber trees in the field, but also fluctuate depending on the period of the day, the orientation (Northern or Southern), relating the line of trees and the season of the year. This study showed that shaded intercropped plants displayed some advantage in a few cases (black pepper plants located at $2 \mathrm{~m}$, and $5 \mathrm{~m}$ between rubber trees, southern side) as regards the photosynthetic rate at midday and afternoon, and especially in summer, when compared to pepper plants cultivated in full sunlight condition, That would be likely related to the to the maintenance of somewhat lower temperature and higher relative humidity in the atmosphere close to the black pepper plant implying some advantage for such consortium system to mitigate the possible effects of future climate changes, like warming.
\end{abstract}

Index terms: Leaf gas exchanges; iWUE; arborization; Piper nigrum.

\begin{abstract}
RESUMO
Plantas de pimenta do reino (Piper nigrum L.) podem apresentar alterações na atividade fotossintética devido a mudanças sazonais. O sistema de consórcio com espécies arbóreas pode representar uma alternativa para mitigar os impactos das mudanças climáticas nas culturas. O objetivo deste trabalho foi avaliar as respostas fisiológicas da fotossíntese em plantas de pimenta do reino em diferentes níveis de sombreamento promovidos pelo cultivo intercalado com árvores de seringueira (Hevea brasiliensis (Willd. Ex A. Juss.) Müll. Arg. O desempenho fotossintético da pimenta do reino ao longo do dia foi avaliado sob o pleno sol e seis níveis de sombreamento. Os resultados mostraram que as variações positivas das trocas gasosas não dependeram exclusivamente da sombra promovida pela distância em relação à linha das árvores de seringueira no campo, mas também dependem do período do dia, a orientação (norte ou sul), relacionando a linha das árvores e a estação do ano. Os resultados indicam que pimenteiras sombreadas em consórcio apresentaram alguma vantagem em alguns casos (plantas de pimenta preta localizadas a $2 \mathrm{~m}$ e $5 \mathrm{~m}$ entre seringueiras no lado sul) quanto à taxa fotossintética ao meio dia e à tarde, especialmente no verão, quando comparadas às plantas de pimenta cultivadas condição de pleno sol, Isso provavelmente estaria relacionado com a manutenção de uma temperatura um pouco mais baixa e umidade relativa mais alta na atmosfera próxima à planta de pimenta preta, o que implicaria alguma vantagem para tal sistema de consórcio mitigar os possíveis efeitos de futuras mudanças climáticas tais como aquecimento.
\end{abstract}

Termos para indexação: Trocas gasosas; iWUE; arborização; Piper nigrum.

\section{INTRODUCTION}

The Piper genus is distributed around the world, and includes more than 700 species with significant commercial and medicinal importance (Meghwal; Goswami, 2013). Black pepper specie is one of the most valued of these species (it may achieve values of 10000 USD per ton), due to its traditional use as a gastronomic ingredient, its nutritional value and antioxidant properties provided by its content of vitamin $\mathrm{C}$, phenolic compounds and carotenoids, as well as due to its importance in the cosmetic and pharmaceutical industries (Huang; Ou; Prior, 2005; Zhu et al., 2012; Bagheri; Manap; Solati, 2014). Vietnam, India, Indonesia, Malaysia and Brazil are the larger producers of $P$. nigrum (FAO, 2017), with total production of more than 400000 tons in the last decade 
(Partelli, 2009, International Pepper Community - IPC, 2015).

As other crops, black pepper production is influenced by environmental conditions, such as, irradiance, soil moisture, air temperature, water availability (Zhu et al., 2012), and soil mineral nutrients (Gontijo et al., 2012). Production has been frequently limited by climatic limiting conditions occurring in the main producing countries. According to the Intergovernmental Panel of Climatic Change (IPCC, 2014), the future climatic scenarios foresee an increment in the incidence of droughts around the globe, particularly in tropical regions, mostly associated to a global decreased water availability that results from altered intra- and inter- annual rainfall patterns, which altogether will severe limit agriculture (Feng; Porporato; Rodriguez-Iturbe, 2015). With the growing concern in global climate changes a large set of studies were performed in the last two decades. Due to its central role on plant growth and yield many of these studies have been focusing the impact/response of the C-assimilatory pathway to warming (Ghannoum et al., 2010; Martins et al., 2016; Rodrigues et al., 2016), water shortage (Delaney; Weaver; Peterson, 2010), salinity (Chaves; Flexas; Pinheiro, 2009; Batista-Santos et al., 2015) and irradiance (Schock et al., 2014), with or without the combined increase of air $\left[\mathrm{CO}_{2}\right]$ that is predicted to contribute to warming (Reddy; Rasineni; Raghavendra, 2010; Kirschbaum, 2011; Martins et al., 2016; Rodrigues et al., 2016).

Under adverse climatic conditions changes in plant C-balance may occur, leading to a reduction in the concentration of intercellular $\mathrm{CO}_{2}$, due to stomatal closure. This has the potential to promote an excessive excitation, leading to photoinhibitory impairments on the photosystem II (PSII) (Souza et al., 2004), and the consequent reduction in photochemical efficiency (expressed as $\mathrm{F}_{\mathrm{v}} / \mathrm{F}_{\mathrm{m}}$ or $\mathrm{F}_{\mathrm{v}}{ }^{\prime} / \mathrm{F}_{\mathrm{m}}{ }^{\prime}$ ) (Flexas et al., 2009; Pinheiro; Chaves, 2011; Zhu et al., 2012). Such reductions in C-assimilation can lead to significant impacts in biomass accumulation, and yield. That is also the case of black pepper crop, with reports of a total yield loss under water deficit combined with high irradiance (Cafer et al., 2006; Showemimo; Olarewaju, 2007), and reduced size and number of shoots and fruits in early stages of the plant development (Rylski; Spigelman, 1982).

The implementation intercropping techniques with tree shading has been used in some tropical crops, aiming at to diminish the effects of extreme climatic conditions and to promote higher sustainability to the agricultural system, improving the plant's physiological performance when compared with full sun plants (Dai et al., 2009;
Zhu et al., 2012; Santos et al., 2015; Oliosi et al., 2016). Under intercrop systems, responses of plants to shading may vary according to the geographical area, seasonality, crop cultivar and agricultural management (Baliza et al., 2012; Zhu et al., 2012; Araujo et al., 2016).

The Rubber tree (Hevea brasiliensis (Willd. ex A. Juss.) Müll. Arg) is the most important species for the production of rubber or latex. Among a wide number of trees used in intercropping systems, rubber tree is known as a good choice for coffee (Araujo et al., 2014; 2016) and Theobroma cacao L. (Monroe; Gama-Rodrigues; Gama-Rodrigues, 2016), having a beneficial impact on these crops, like decreased luminosity and temperature throughout the day, promoting greater leaf expansion and increase in chlorophyll b content, total chlorophyll content.

In the context of predicted future climate changes (and limitations), despite the importance of black pepper crop and the promising results obtained for several crops using intercropping systems with tree species, there is a total absence of data regarding the potential benefits the rubber of tree intercropping with black pepper. Therefore, we aim at to evaluate the impact of intercropping black pepper with rubber tree regarding the photosynthetic functioning. Several levels of shade were analyzed, concerning the distance of black pepper plants to the rubber trees in different seasons of the year, in order to characterize possible mitigation effects of likely future climate changes.

\section{MATERIAL AND METHODS}

\section{Plant material and experimental design}

The experiment was performed using five years old Piper nigrum L. cv. Bragantina (black pepper) plants, planted in rows with a $3 \times 2 \mathrm{~m}$ spacing irrigated system, on a rural property in Boa Esperança, Espírito Santo state, Brazil (18 30' 24"S $\left.40^{\circ} 17^{\prime} 45^{\prime \prime} \mathrm{W}\right)$, and at $120 \mathrm{~m}$ altitude in a flat relief. The soil texture of the experimental area was classified as a dystrophic Red Latosol (Oxisol) (Embrapa, 2013). Black pepper plants planted in rows with 2,5 x 2 $\mathrm{m}$ spacing with five age were intercropped with Hevea brasiliensis (Willd. ex A. Juss.) Müll. Arg. (clone FX 3864) (rubber tree) plants, with the same age, planted in rows with $16 \times 4 \times 2 \mathrm{~m}$ spacing, resulting in five rows of black pepper followed by two rows of rubber trees (Figure 1). All rows were oriented $70^{\circ}$ northwest. During the experimental period, average of rubber trees diameter at breast height was $c a .20 \mathrm{~cm}$, plant height was $10 \mathrm{~m}$ and canopy diameter of $c a .4 \mathrm{~m}$. The experiment consisted of six treatments, with five shading levels, related to the distance to the 
rubber tree, and one treatment with in plants managed under full sunlight exposure. Three distances from the black pepper plants to the rubber trees were considered: $\mathrm{T} 2$ at $2 \mathrm{~m}$, and T5 at $5 \mathrm{~m}$, on both southern (S) and northern (N) sides, as well as T8 located at $8 \mathrm{~m}$ in the central line between rubber trees. The sixth treatments considered black pepper plants under full sunlight explosure (Tsun) with the same age, planted an adjacent area without rubber tree implantation.

\section{Microclimate characterization}

The measurements of irradiance, temperature and relative humidity were performed with an external data logger (HOBO U12, Onset HOBO Data Loggers, Bourne, MA, USA), placed at a $3 \mathrm{~m}$ height above the black pepper tree rows. Data were recorded at every $10 \mathrm{~min}$ for each evaluation period (7:00-9:00; 11:00-13:00; 15:00- 17:00). The climatic data were reported on 03/08/2014 (summer), 05/08/2014 (autumn) 08/09/2014 (winter) and 11/26/2014 (spring) (data not shown).

\section{Leaf gas exchanges}

The leaf net photosynthesis rates $(A)$, stomatal conductance to water vapor $\left(g_{s}\right)$, internal $\mathrm{CO}_{2}$ concentration $\left(C_{i}\right)$ and transpiration $\left(T_{r}\right)$ were obtained under photosynthetic steady-state conditions in four young
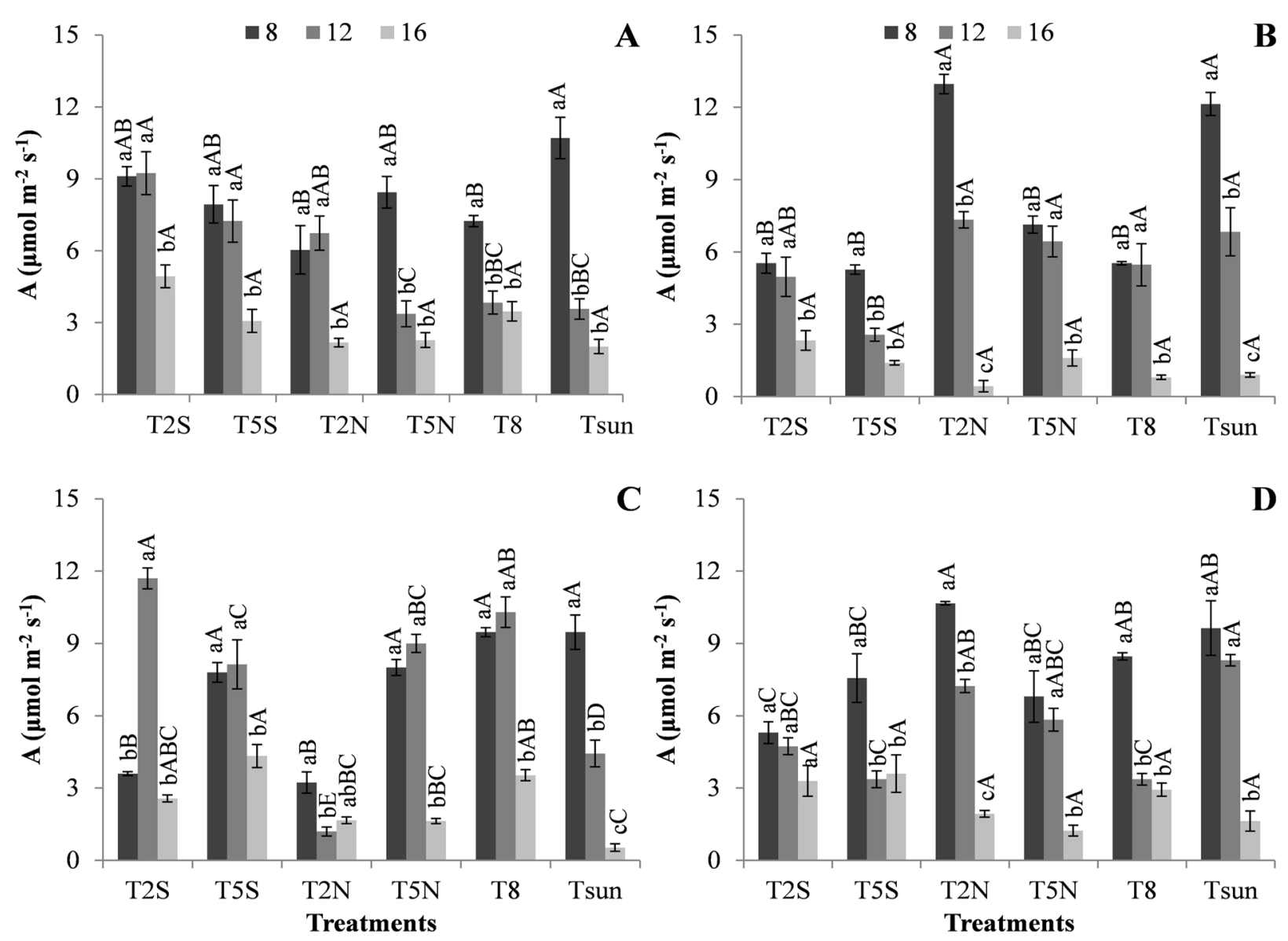

Figure 1: The leaf rates of net photosynthesis $(A)$ values at 8:00 (early morning), 12:00 (late morning), and 16:00 (afternoon) in summer (A), autumn (B), winter (C) and spring (D) seasons, for the six treatments related to black pepper distances to the rubber trees: at $2.0 \mathrm{~m}$ from on the southern (T2S) and northern (T2N) sides; at $5.0 \mathrm{~m}$ on the southern (T5S) and northern (T5N) sides; at $8.0 \mathrm{~m}$ (T8), which was the central row of black pepper, and unshaded black pepper (Tsun). For each parameter, the mean values $\pm S E(n=6)$ followed by different letters express significant differences between daily hours within each shade level $(a, b, c)$, or between shade levels within each hour of the day (A, B, C, D), always separately for each season. 
fully expanded leaves of four pepper plants in each plot along the day: 8:00 (7:00-09:00, early morning), 12:00 (11:00-13:00, late morning) and 16:00 (15:00- 17:00, afternoon) at summer, autumn, winter and spring.. A portable open-system infrared gas analyzer (CIRAS-II, PP Systems, UK) was used, with settings to external $\left[\mathrm{CO}_{2}\right]$ supply of $\left(400 \mu \mathrm{L} \mathrm{L}^{-1}\right)$, irradiance $\left(800 \mu \mathrm{mol} \mathrm{CO}_{2}\right.$ $\left.\mathrm{m}^{-2} \mathrm{~s}^{-1}\right)$, and temperature $\left(25^{\circ} \mathrm{C}\right)$. Leaf instantaneous water-use efficiency (iWUE) was calculated as the $A$-to- $\operatorname{Tr}$ ratio, representing the units of assimilated $\mathrm{CO}_{2}$ per unit of water lost through transpiration. The internal-to-ambient $\mathrm{CO}_{2}$ concentration ratio $\left(C_{i} / C_{a}\right)$ was also assessed.

\section{Light steady-state fluorescence parameters}

Chlorophyll (Chl) $a$ fluorescence parameters were determined on the same leaves used for gas exchange measurements, using the same CIRAS-II system coupled with the universal automatic PLC6 leaf cuvette fluorometer (PP-Systems), following the formula discussed elsewhere (Kramer et al., 2004; Schreiber, 2004). This set of parameters was evaluated under photosynthetic steady-state conditions, under $700-800 \mu \mathrm{mol} \mathrm{m}^{-2} \mathrm{~s}^{-1}$ of actinic light and superimposed saturating flashes (10), and included $\mathrm{q}_{\mathrm{L}}, \mathrm{Y}_{\text {(II) }}, \mathrm{F}_{\mathrm{v}}{ }^{\prime} / \mathrm{F}_{\mathrm{m}}{ }^{\prime}$ (Kramer et al., 2004; Klughammer; Schreiber, 2008), and $\mathrm{F}_{\mathrm{s}} / \mathrm{F}_{\mathrm{m}}$ ' (Stirbet; Govindjee, 2011). The $\mathrm{F}_{\mathrm{o}}$ ', needed for the quenching's determination was obtained in the dark immediately after actinic light was switched off and before the first fast phase of fluorescence relaxation kinetics. The ratio $\mathrm{F}_{\mathrm{v}}{ }^{\prime} / \mathrm{F}_{\mathrm{m}}{ }^{\prime}$ represents the actual PSII efficiency of energy conversion under light exposure, and $\mathrm{q}_{\mathrm{L}}$ represents the proportion of energy trapped by PSII open centers and driven to photochemical events, based on the concept of interconnected PSII antennae, whereas $Y_{(I I)}$, represents the estimate of the quantum yield of photosynthetic non-cyclic electron transport. The $\mathrm{F}_{\mathrm{s}} / \mathrm{F}_{\mathrm{m}}$, ratio is the predictor of the constant rate of PSII inactivation.

\section{Statistical analysis}

The experimental design was totally randomized, in subdivided plots ( $\mathrm{plot}=$ shade and subplot treatments $=$ time of the day). The measured and calculated parameters were analyzed using a two-way ANOVA, during the whole observed periods to evaluate the differences between several levels of imposed shade, related to the distance of black pepper to the rubber trees, between hours of the day, as well as their interaction, followed by a Tukey's test to compare mean values, at $5 \%$ probability.

\section{RESULTS AND DISCUSSION}

\section{Variations of leaf gas exchanges}

Leaf gas exchanges of black pepper, regarding net photosynthesis rates $(A)$, stomatal conductance $\left(g_{s}\right)$, internal-to-ambient $\mathrm{CO}_{2}$ concentration ratio $\left(C_{i} / C_{a}\right)$ and the instantaneous water-use efficiency (iWUE), were positively influenced by shading (distance to the rubber tree line), time of the day, Southern or Northern orientation, and season of the year.

In detail, a $45 \%$ reduction was observed in $A$, at 8:00, from summer to autumn, with prominence in winter and spring, was observed in T2S. On the other hand, T2N showed a $50 \%$ increment in $\mathrm{CO}_{2}$ assimilation between summer season (Figure 1A) and autumn season (Figure 1B), with subsequent reduction in winter season (Figure 1C) and increment once again in the spring (Figure 1D). Treatments T5S and T5N showed a slight reduction in $A$ between summer and autumn and remained constant during winter and spring (Figure 1).

Significant $\mathrm{CO}_{2}$ assimilation variations were observed amongst diurnal measurements in all seasons. In a general, $A$ in black pepper plants under full sunlight explosure maintained a similar pattern throughout the year, full sun plants plants usually showed the maximal $A$ values at 8:00, although accompanied with some shade treatments that changed for each season. (T2S, T5S, T5N in summer; $\mathrm{T} 2 \mathrm{~N}$ in autumn; T5S, T5N, T8 in winter; T2N, T8 in spring). However, full sun plants usually showed as well the greater decreases between 8:00 and 12:00, and their values at 16:00 were always amongst the lowest ones. For most shading treatments, maximum values of $A$ were observed during the morning period (8:00 and/or 12:00), decreasing afterwards (16:00) for all seasons of the year. Such $A$ decrease in the afternoon was likely related to the concomitant irradiance reduction from 12:00 to 16:00. However, in spring determinations $A$ was reduced probably linked to the $\mathrm{g}_{\mathrm{s}}$ drop, but not to irradiance (that did not decrease at 16:00). Such limitation of $A$ by $g_{s}$ (Figure 2) could had happened as well for autumn as reflected in the reduction of $C_{i} / C_{a}$ values at 12:00 and 16:00 (Figure 3B). In shaded plants, with exception of $\mathrm{T} 2 \mathrm{~N}$ which showed responses similar to black pepper plants under full sunlight explosure (autumn and spring), $A$ was significantly lower in $\mathrm{T} 2 \mathrm{~S}$ and $\mathrm{T} 2 \mathrm{~N}$ at 8:00, in winter (Figure $1 \mathrm{C}$ ). In summer, autumn and spring T2S preserved the same rate of $\mathrm{CO}_{2}$ net assimilation until 12:00, showing a sharp drop only at 16:00, a behavior also observed in T5S during summer (Figure 1A) and winter (Figure 1C), as well as T5N and T8 in autumn (Figure 1B) and winter (Figure 1C). 
The $g_{\mathrm{s}}$ (Figure 2) followed in most cases the same pattern observed in $A$. black pepper plants under full sunlight explosure consistently showed the higher $\mathrm{g}_{\mathrm{s}}$ values at 8:00, followed by strong reductions both at 12:00 and 16:00, irrespective of season. Despite the lower values of $g_{s}$ at 8:00, when compared to black pepper plants under full sunlight explosure, T2S plants maintained or increased (the latter in winter) the $g_{s}$ values by 12:00. Similar patterns were observed in T2N (summer), T5S and $\mathrm{T} 5 \mathrm{~N}$ (winter). The highest values of $g_{s}$ at 12:00 were observed in treatments $\mathrm{T} 5 \mathrm{~S}$ and $\mathrm{T} 5 \mathrm{~N}$, in winter and spring (Figure $2 \mathrm{C}, \mathrm{D}$ ), suggesting that a different behavior might be influenced by Northern or Southern orientation.
Independently from luminosity and $g_{s}$, the $C_{i} / C_{a}$ ratio was similar amongst treatments in the summer, with somewhat higher values in the morning and a tendency to decrease (usually non-significant) in the afternoon (Figure 3A). However in autumn (T2N, T8) and winter (T2S, T2N, T5N, T8, Tsun) a different pattern was observed, with $\mathrm{Ci} / \mathrm{Ca}$ ratio values rising in the afternoon period (Figure $4 \mathrm{~B}, \mathrm{C}$ ).

The instantaneous water-use efficiency (iWUE) between full sun and shaded black pepper plants in summer showed only small differences (Figure 4A), although black pepper plants under full sunlight explosure showed significantly lower values at 12:00 and 16:00. In the other
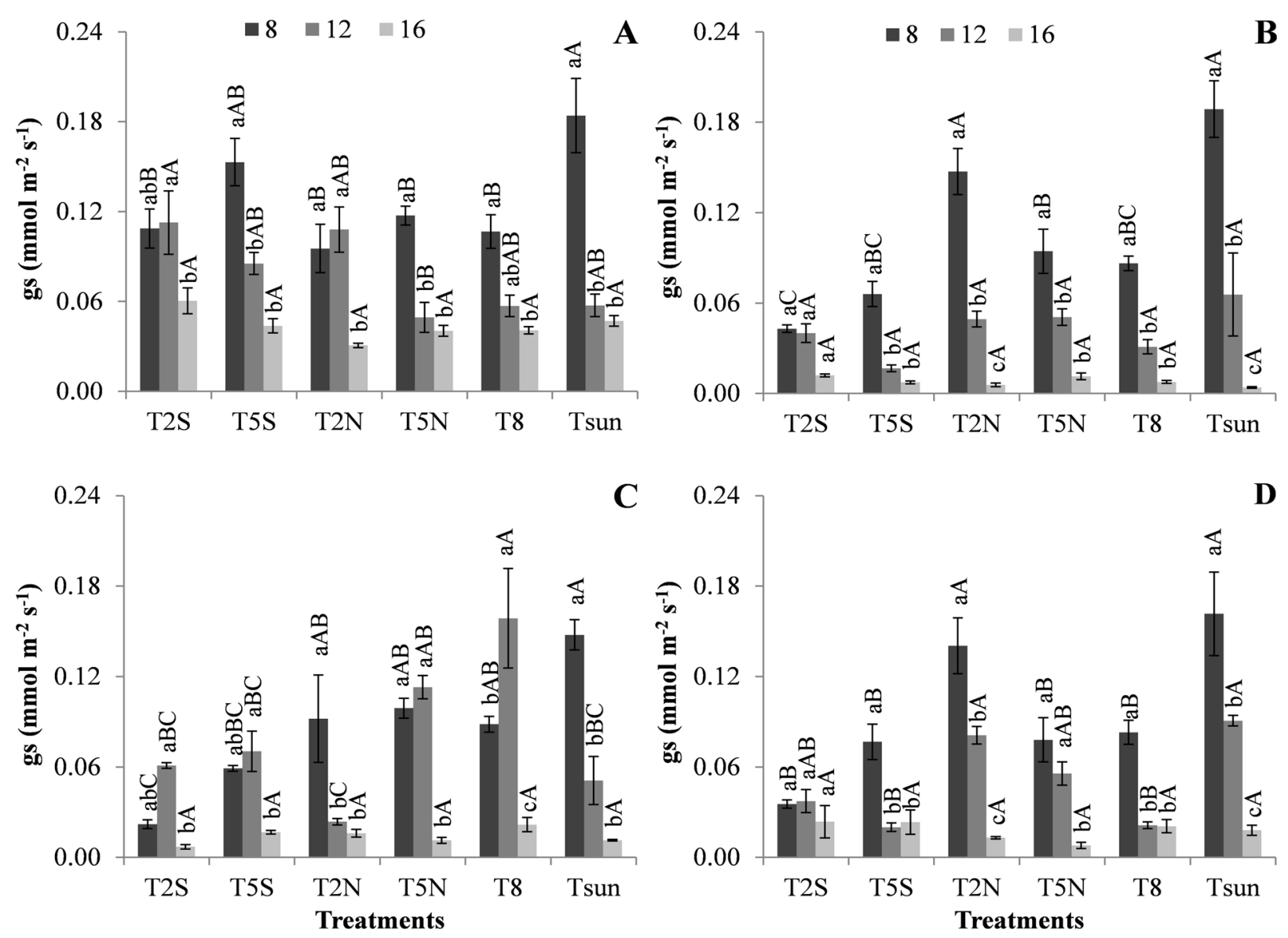

Figure 2: The leaf rates of stomatal conductance to water vapor $\left(g_{s}\right)$ values at 8:00 (early morning), 12:00 (late morning), and 16:00 (afternoon) in summer (A), autumn (B), winter (C) and spring (D) seasons, for the six treatments related to black pepper distances to the rubber trees: at $2.0 \mathrm{~m}$ from on the southern (T2S) and northern (T2N) sides; at $5.0 \mathrm{~m}$ on the southern (T5S) and northern (T5N) sides; at $8.0 \mathrm{~m}$ (T8), which was the central row of black pepper, and unshaded black pepper (Tsun). For each parameter, the mean values $\pm S E(n=6)$ followed by different letters express significant differences between daily hours within each shade level $(a, b, c)$, or between shade levels within each hour of the day (A, B, C, D), always separately for each season. 
three seasons all treatments showed higher iWUE values than in summer (except T2N in winter). In these seasons, shaded plants located nearest to the rubber trees had the higher values in autumn (T2S, Figure 4B), winter and spring (T2S and T5S, Figure 4 C,D), showing variations during the day and higher values usually at 8:00 and/or 16:00, therefore, showing that shaded plants were more efficient during most part of the day. The lowest values for iWUE were observed in T2N during winter, but black pepper plants under full sunlight explosure showed the lowest iWUE values at 16:00 in most part of the year (summer, winter, spring) (Figure 4).

\section{Changes in light steady-state fluorescence parameters}

In general, the evaluated photosynthetic related parameters, determined under light steady-state fluorescence conditions, showed much more moderate changes than $A$ along the day, and only a few differences between shading levels, or even between seasons.

Values of the quantum yield of photosynthetic non-cyclic electron transport $\left(\mathrm{Y}_{(\mathrm{II})}\right)$ did not show any significant change along the day (within each shade level) or for each hour of day when comparing the several shade treatments (Figure 5). The same was observed in the
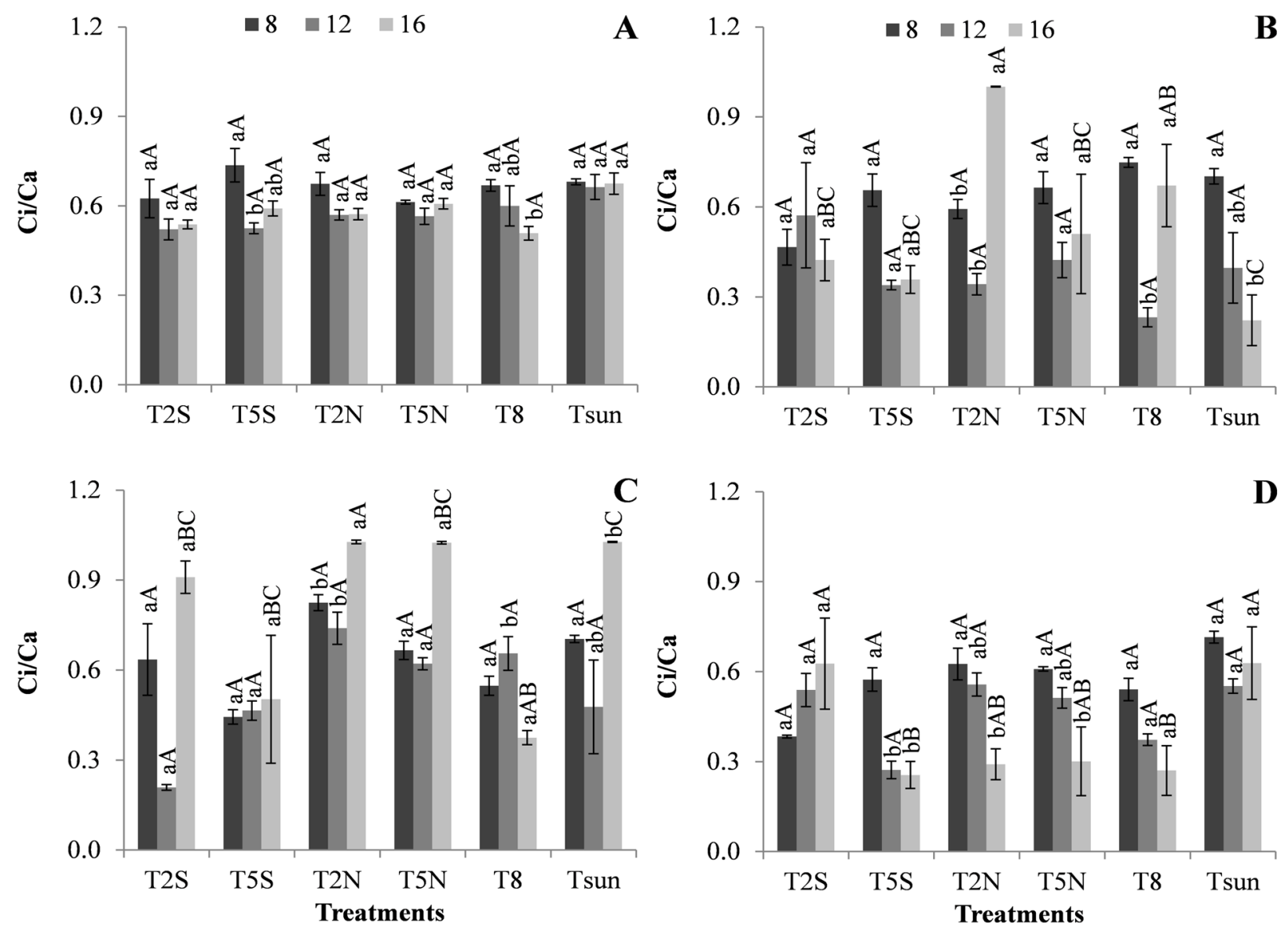

Figure 3: The leaf rates of ratio between the concentration and $\mathrm{CO}_{2}$ environment internal $(\mathrm{Ci} / \mathrm{Ca})$ values at 8:00 (early morning), 12:00 (late morning), and 16:00 (afternoon) in summer (A), autumn (B), winter (C) and spring (D) seasons, for the six treatments related to black pepper distances to the rubber trees: at $2.0 \mathrm{~m}$ from on the southern (T2S) and northern (T2N) sides; at $5.0 \mathrm{~m}$ on the southern (T5S) and northern (T5N) sides; at $8.0 \mathrm{~m}$ (T8), which was the central row of black pepper, and unshaded black pepper (Tsun). For each parameter, the mean values $\pm S E(n=6)$ followed by different letters express significant differences between daily hours within each shade level $(a, b, c)$, or between shade levels within each hour of the day $(A, B, C, D)$, always separately for each season. 
other seasons, with a few exceptions, namely in $\mathrm{T} 2 \mathrm{~N}$ and T5N that tended to higher values at 12:00. However, in general black pepper plants under full sunlight explosure values were similar (or somewhat higher) than those of the shaded plants.

The efficiency of energy trapped by open reaction centers by the PSII $\left(F_{v}{ }^{\prime} / F_{m}{ }^{\prime}\right)$ was not affected by the shade level or seasonality. However, treatments TS2 tended to higher values in the early morning, significantly in summer and spring (Figure 6 A,D). The same tendency of higher $F_{v}{ }^{\prime} / F_{m}{ }^{\prime}$ values at 8:00 was also observed in most T2, T5, and $\mathrm{T} 8$ plants.
Amongst the studied fluorescence parameters, the variable proportion of energy trapped by the PSII and driven to photochemical events $\left(q_{L}\right)$, was the one with greater changes. In summer, all shade treatments followed similar patterns along the day, with the highest value observed by 12:00 (Figure 7 A). Black pepper plants under full sunlight explosure plants showed the highest mean values along the day in autumn (Figure $7 \mathrm{~B}$ ), whereas the shade treatments presented minimal and maximal values at 8:00 and 12:00, respectively. In winter (Figure $7 \mathrm{C}$ ) the Southern and Nothern oriented plants showed the global lower and higher values, with T8 and Tsun showing
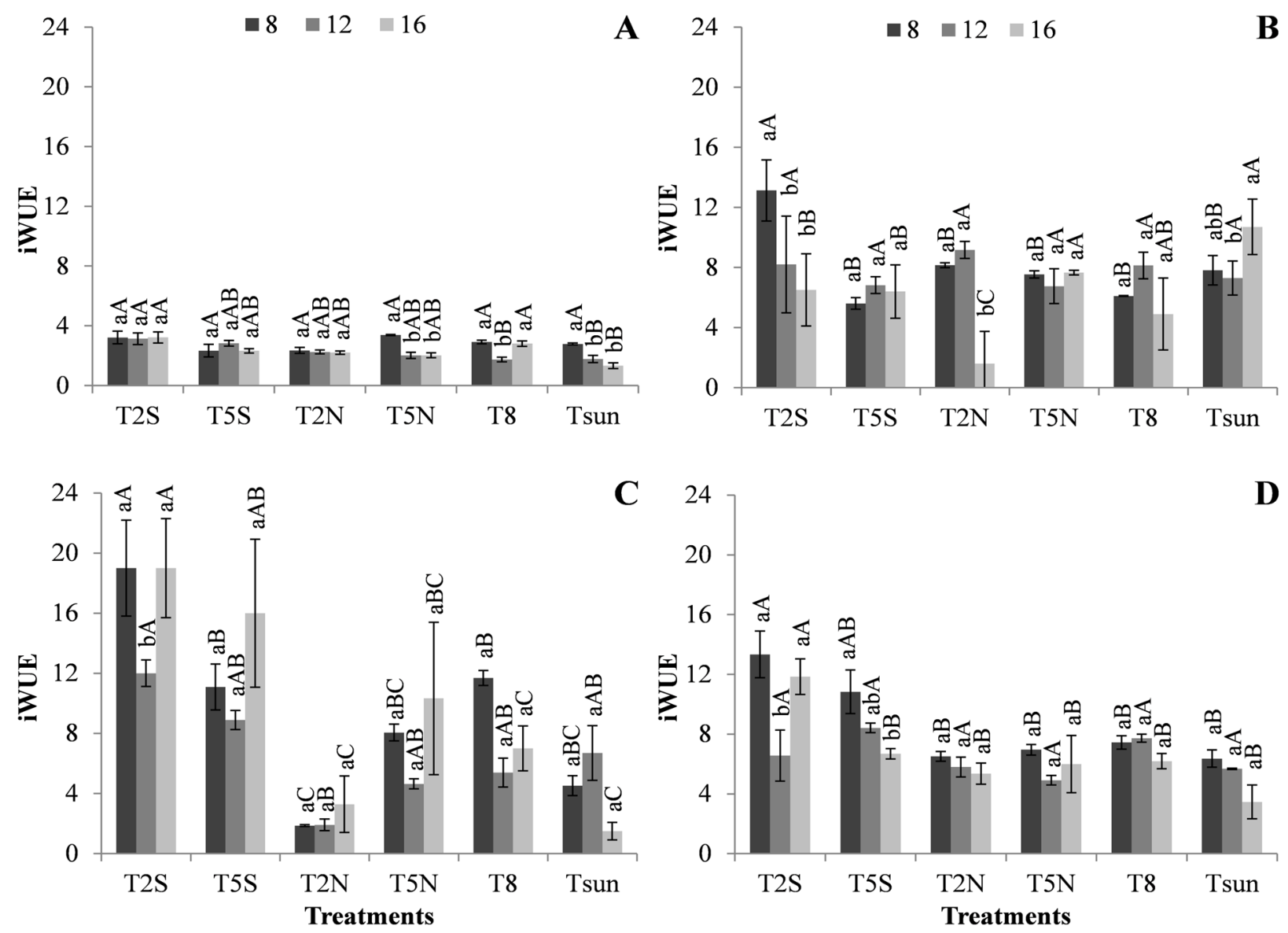

Figure 4: The leaf rates of ratio between the concentration and $\mathrm{CO}_{2}$ environment internal $(\mathrm{Ci} / \mathrm{Ca})$ values at 8:00 (early morning), 12:00 (late morning), and 16:00 (afternoon) in summer (A), autumn (B), winter (C) and spring (D) seasons, for the six treatments related to black pepper distances to the rubber trees: at $2.0 \mathrm{~m}$ from on the southern (T2S) and northern (T2N) sides; at $5.0 \mathrm{~m}$ on the southern (T5S) and northern (T5N) sides; at $8.0 \mathrm{~m}$ (T8), which was the central row of black pepper, and unshaded black pepper (Tsun). For each parameter, the mean values $\pm S E(n=6)$ followed by different letters express significant differences between daily hours within each shade level $(a, b, c)$, or between shade levels within each hour of the day (A, B, C, D), always separately for each season. 
intermediate values. Finally, in spring (Figure 7 D) higher values were observed in late morning or in the afternoon in all treatments. Interestingly, T2S showed the lowest (8:00) and the highest (12:00) $q_{L}$ values in this season.

With a few exceptions, the predictor of the rate constant of PSII inactivation $\left(F_{s} / F_{m}{ }^{\prime}\right)$ showed a similar behavior for all shade levels, leaf orientation and season of the year. Still, this parameter showed lower values in black pepper plants under full sunlight explosure plants in autumn (Figure $8 \mathrm{~B}$ ) when compared to shaded plants.

This work reports for the first time the photosynthetic physiological responses of black pepper in an intercropped system under field conditions, in order to evaluate possible mitigating effects of shadow levels in a context of future climatic changes.

Leaf photosynthetic rates clearly differed between full sun plants and most shading treatments (including Northern or Southern orientation) along the day, irrespective of the season of the year. In fact, $A$ values in Tsun were always amongst the maximal values observed in the early morning (Figure 1), linked to the highest $g_{s}$ values found in Tsun plants (Figure 2). Such high $g_{s}$ values allowed the maintenance of an adequate $\mathrm{CO}_{2}$ supply to chloroplast, as reflected in the stable $C_{i} / C_{a}$ values at 8:00 along the entire year (Figure 3), since stomatal conductance is directly linked with the photosynthetic
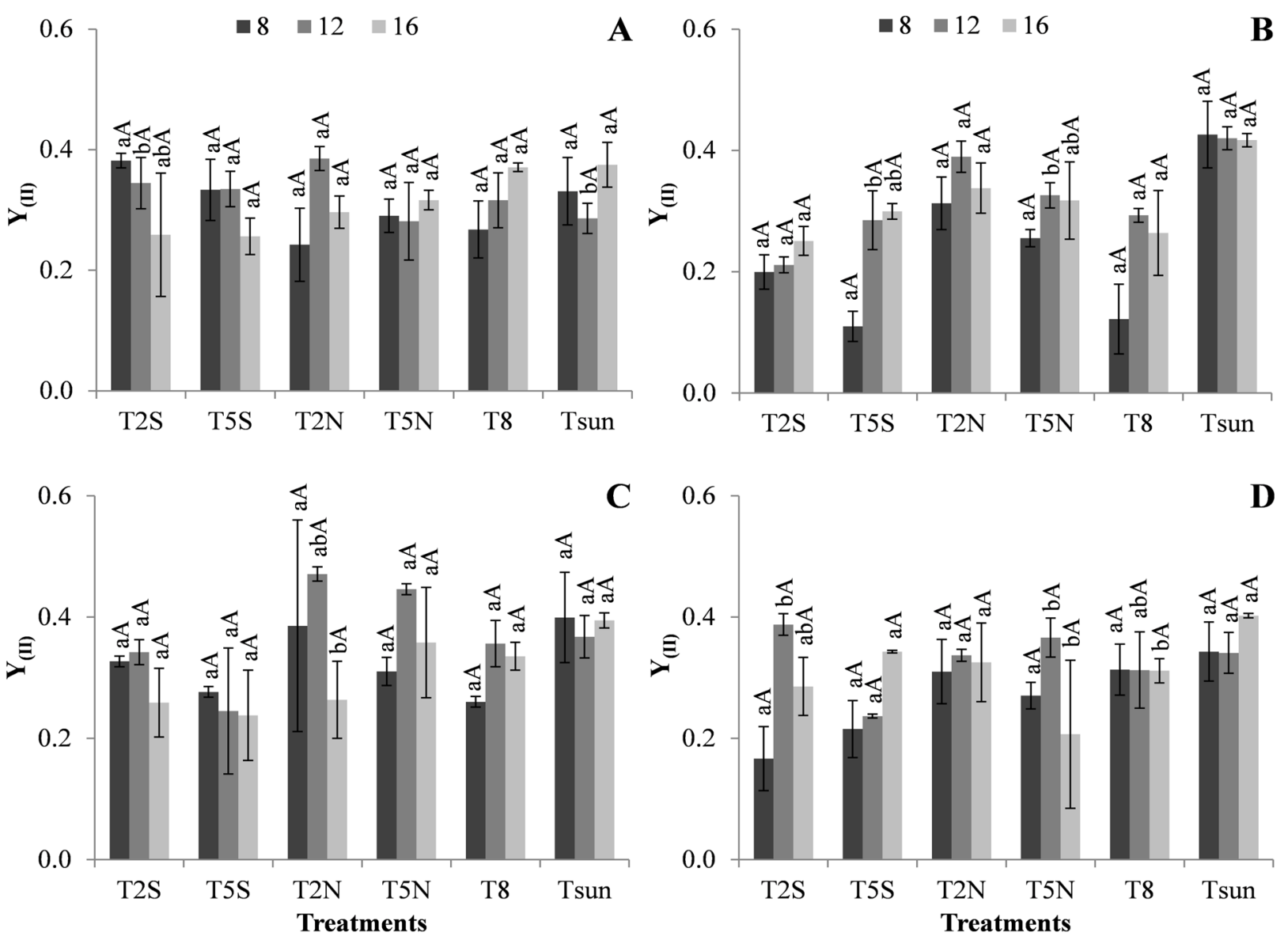

Figure 5: Estimate of the quantum yield of photosynthetic non-cyclic electron transport $Y_{(I)}$ values at 8:00 (early morning), 12:00 (late morning), and 16:00 (afternoon) in summer (A), autumn (B), winter (C) and spring (D) seasons, for the six treatments related to black pepper distances to the rubber trees: at $2.0 \mathrm{~m}$ from on the southern (T2S) and northern (T2N) sides; at $5.0 \mathrm{~m}$ on the southern (T5S) and northern (T5N) sides; at $8.0 \mathrm{~m}$ (T8), which was the central row of black pepper, and unshaded black pepper (Tsun). For each parameter, the mean values $\pm S E(n=6)$ followed by different letters express significant differences between daily hours within each shade level $(a, b, c)$, or between shade levels within each hour of the day (A, B, C, D), always separately for each season. 
rate and coordinated by $\mathrm{CO}_{2}$ in the mesophyll, tending to keep $C_{i} / C_{a}$ ratio at a fairly constant value (Sharkey; Raschke, 1981). Consequently, these plants were able to photochemically use the greater irradiance levels that reach the leaf surface, although with a lower $i W U E$ than in several shading treatments, mostly in winter and spring (Figure 4). This greater photosynthetic activity was also sustained by higher photochemical efficiency of PSII ( $F_{v}$ '/ $\left.F_{m}{ }^{\prime}\right)$ (Figure 6), photochemical energy use $\left(q_{L}\right)$ (Figure 7), and electron transport $\left(Y_{(I I)}\right)$ (Figure 5) levels, further contributing to a lower inactivation status of the PSII $\left(F_{s} / F_{m}{ }^{\prime}\right)$, that is, maintaining a high efficiency in light capture and its photochemical use as measured through light steady-state fluorescence parameters (Wang et al., 2007; Zhu et al., 2012). Nevertheless, it seems noteworthy that $\mathrm{T} 2 \mathrm{~N}$ (autumn and spring) and $\mathrm{T} 5 \mathrm{~N}$ (summer and winter) fully accompanied Tsun plants in most of the analyzed parameters (except $\mathrm{q}_{\mathrm{L}}$ ), especially as regards the maintenance of high $A$ values under lower irradiance levels than at black pepper plants under full sunlight explosure, suggesting a higher energy capture efficiency by shaded plants or that Tsun plants were functioning above light saturating levels for $\mathrm{C}$-assimilation.

Plant responses to environmental factors usually result in changes in the diurnal photosynthetic parameters (Palmer, 2014; Li et al., 2015). Considered as a plant
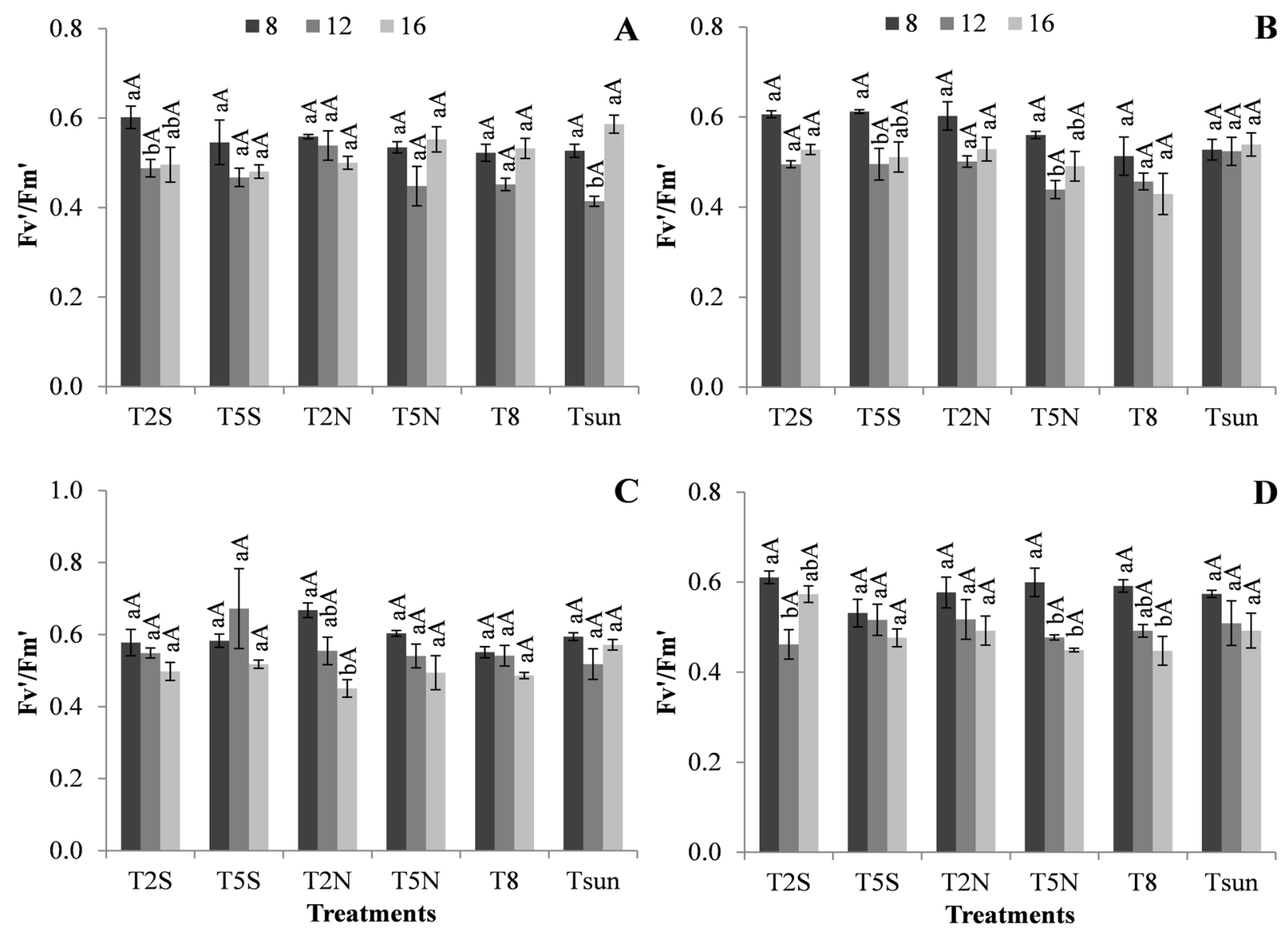

Figure 6: The actual PSII efficiency of energy conversion under light exposure values $\left(F_{v}{ }^{\prime} / F_{m}{ }^{\prime}\right)$ values at 8:00 (early morning), 12:00 (late morning), and 16:00 (afternoon) in summer (A), autumn (B), winter (C) and spring (D) seasons, for the six treatments related to black pepper distances to the rubber trees: at $2.0 \mathrm{~m}$ from on the southern (T2S) and northern (T2N) sides; at $5.0 \mathrm{~m}$ on the southern (T5S) and northern (T5N) sides; at $8.0 \mathrm{~m}$ (T8), which was the central row of black pepper, and unshaded black pepper (Tsun). For each parameter, the mean values $\pm S E(n=6)$ followed by different letters express significant differences between daily hours within each shade level $(a, b, c)$, or between shade levels within each hour of the day (A, B, C, D), always separately for each season. 
defense strategy against excessive water loss, this fact, is usually attributed to an increase of radiation and temperature, typical conditions during diurnal period which has been reported in different species, in leaves and whole plants (Zhu et al., 2012; Morandi et al., 2014; Li et al., 2015; Ferraz et al., 2016; Rodrigues et al., 2016). In the present study, this fact also occurred as a result of the relative humidity reduction during the afternoon period, associated to a significant reduction in the stomatal conductance (Figure 2).

Along the day (12:00 and 16:00) leaf gas exchanges of Tsun suffered the largest changes, with severe reduction of $A$ (which became negligible in winter in the afternoon) and $g_{s}$ values, likely related to increased air temperature and irradiance along the day, which were accompanied by a stronger reduction in air humidity, and, therefore, a higher atmospheric evaporation demand. Notably, black pepper plants under weaker shading levels (T5N, T5S and T8) showed similar $A$ and $g_{s}$ patterns to that of Tsun, along the year, particularly in summer. However, although $A$ and $g_{s}$ showed large parallel decreases in Tsun, such $A$ reductions would have resulted from lower $\mathrm{CO}_{2}$ availability to the carboxylation sites due to stomata closure only in autumn (when $C / C_{a}$ was reduced). Such impact on photosynthesis
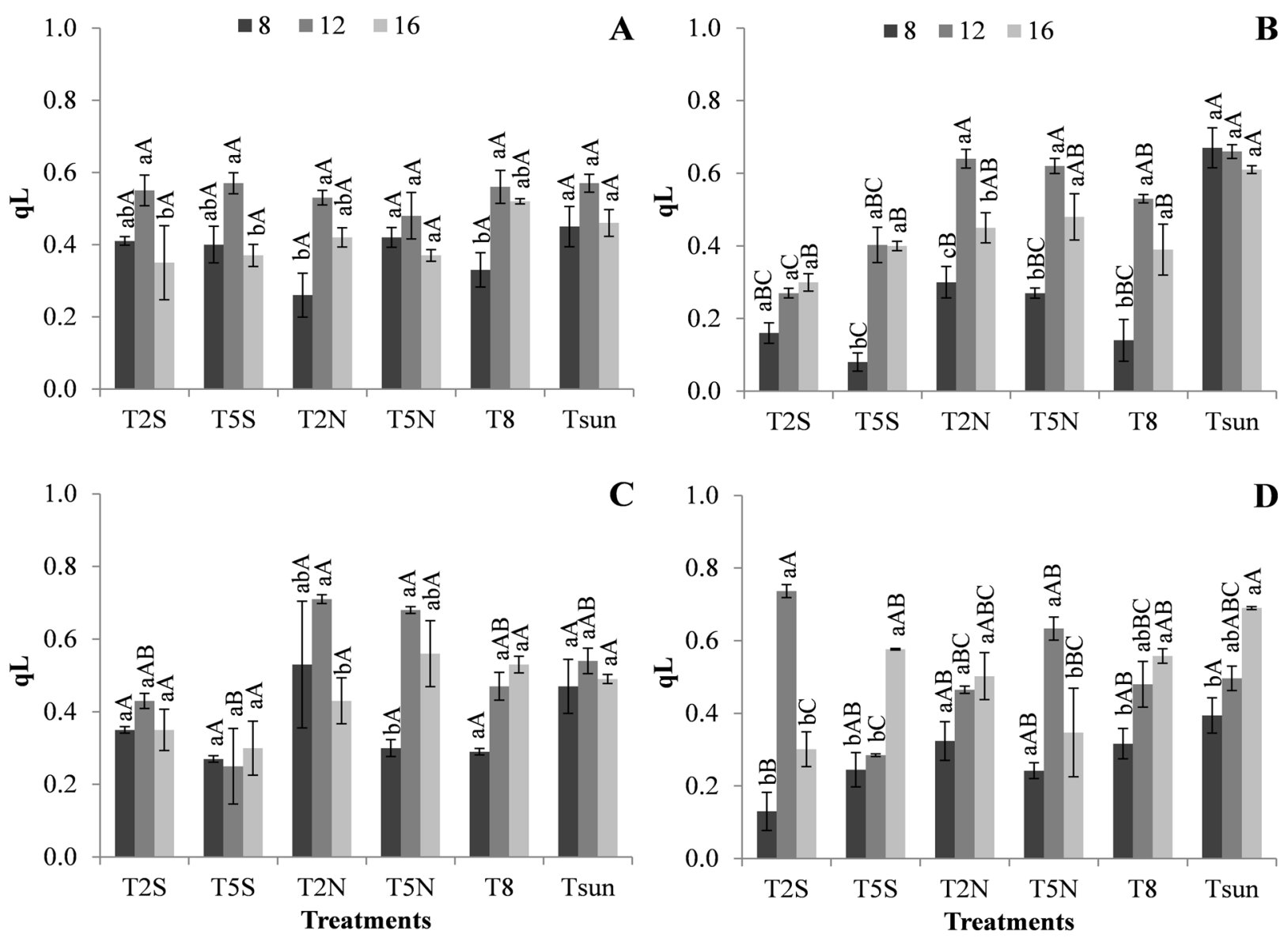

Figure 7: Proportion of energy trapped by PSII open centers and driven to photochemical events values $\left(q_{1}\right)$ values at 8:00 (early morning), 12:00 (late morning), and 16:00 (afternoon) in summer (A), autumn (B), winter (C) and spring (D) seasons, for the six treatments related to black pepper distances to the rubber trees: at $2.0 \mathrm{~m}$ from on the southern (T2S) and northern (T2N) sides; at $5.0 \mathrm{~m}$ on the southern (T5S) and northern (T5N) sides; at 8.0 $\mathrm{m}$ (T8), which was the central row of black pepper, and unshaded black pepper (Tsun). For each parameter, the mean values $\pm S E(n=6)$ followed by different letters express significant differences between daily hours within each shade level $(a, b, c)$, or between shade levels within each hour of the day (A, B, C, D), always separately for each season. 
by reduced stomatal conductance under conditions of lowered water availability is widely observed in different species (Delaney; Weaver; Peterson, 2010; Sui et al., 2012; Wu et al, 2014). In the other seasons, the $C_{i} / C_{a}$ value in Tsun plants did not decrease, therefore no lack of $\mathrm{CO}_{2}$ would have occurred at the chloroplast level (Medeira et al., 2012). Furthermore, there were not observed decreases of the photochemical efficiency of PSII, electron transport, and energy driven to photochemical events, whereas PSII inactivation did not increase. In this way, these unaltered processes did not account for the severe $A$ reductions. In fact, these photosynthetic related parameters $\left(F_{v}{ }^{\prime} / F_{m}\right.$, $\left.Y_{(I I)}, q_{L}, F_{s} / F_{m}\right)$ pointed to a better functional status of the
Tsun plants. Instead, such impact on the photosynthetic metabolism (globally reflected on $A$ ) could had resulted from impairments on the photosynthetic enzymes, due to their sensitivity to high temperatures, observed in all seasons but winter in Tsun plants, as reported to occur under supra-optimal temperatures in other species (Rodrigues et al, 2016).

On the other hand, a few shaded treatments showed lower $A$ decreases (or even increases) at 12:00, and maintained higher $A$ values than Tsun plants by 12:00 and 16:00, even high lower irradiance levels. That was the case of T2S and T5S plants in summer and winter, and T8 in winter, with impacts on higher $i W U E$ (only in winter). The
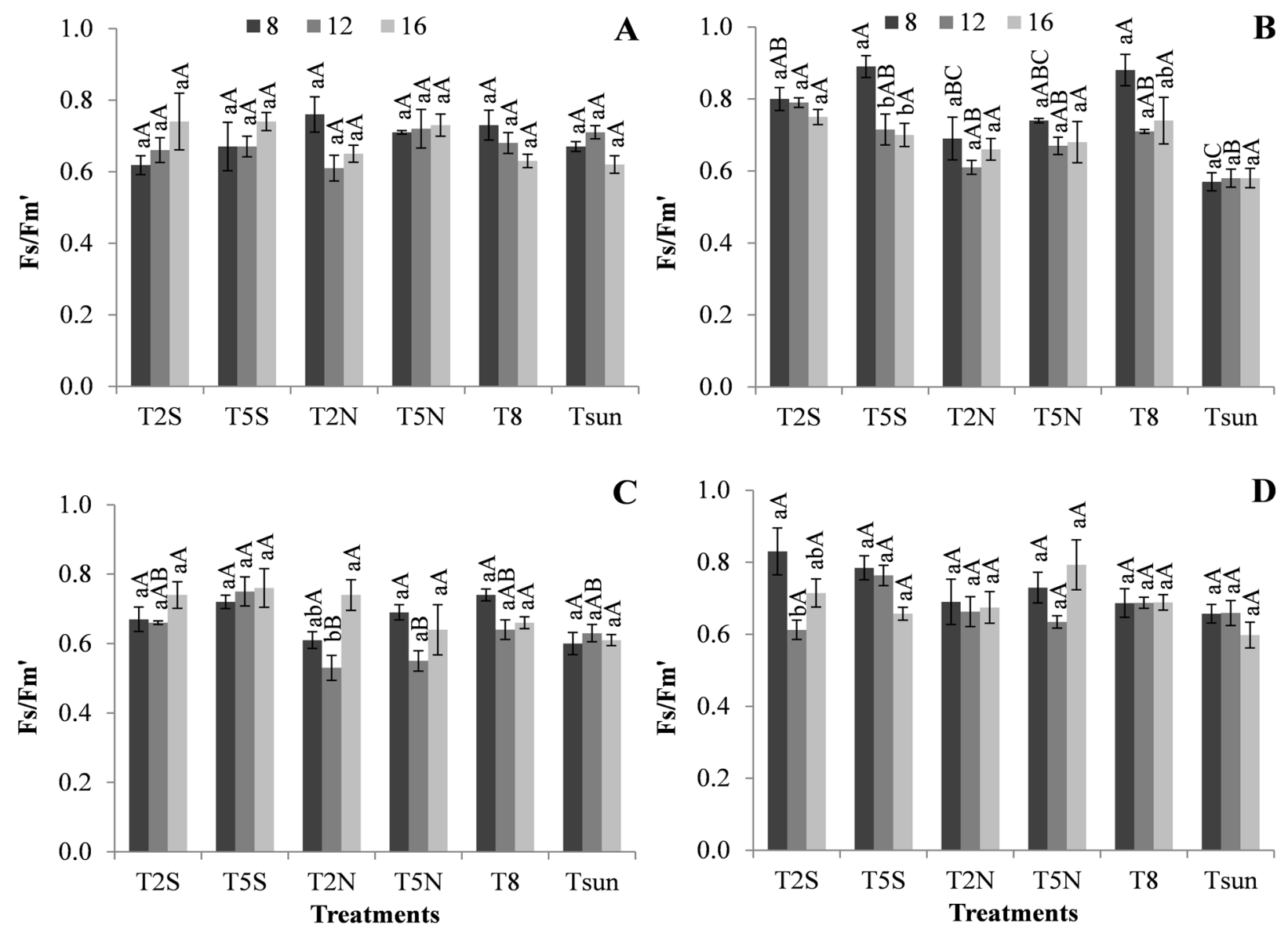

Figure 8: Predictor of the rate constant of PSII inactivation values $\left(F_{s} / F_{m}{ }^{\prime}\right)$ values at 8:00 (early morning), 12:00 (late morning), and 16:00 (afternoon) in summer (A), autumn (B), winter (C) and spring (D) seasons, for the six treatments related to black pepper distances to the rubber trees: at $2.0 \mathrm{~m}$ from on the southern (T2S) and northern (T2N) sides; at $5.0 \mathrm{~m}$ on the southern (T5S) and northern (T5N) sides; at $8.0 \mathrm{~m}$ (T8), which was the central row of black pepper, and unshaded black pepper (Tsun). For each parameter, the mean values $\pm S E(n=6)$ followed by different letters express significant differences between daily hours within each shade level $(a, b, c)$, or between shade levels within each hour of the day (A, B, C, D), always separately for each season. 
better $A$ performance in these shaded plants was not related with higher values of $g_{s}$ or with a better photochemical functioning or efficiency (as given by the fluorescence parameters), since they did not differ from those observed in Tsun plants. At least for summer, the lower temperatures found in T2S and T5S by 12:00 and 16:00 might have contributed to the higher $A$ values, when compared to those of Tsun plants, suggesting that during the hottest periods of the year shade may improve the photosynthetic functioning of black pepper, as previously reported for other species (Dai et al., 2009; Zhu et al., 2012). It is well known that shading causes microclimatic changes in many agricultural crops, especially in plants located in the nearest lines to the trees, resulting in physiological and growth alterations (Pezzopane et al., 2010; Araújo et al., 2015; Oliosi et al., 2016). Such impacts may depend on the nature, density, duration and season of the shade and well as on the current climatic conditions and local climate, genotype, plant age, among other factors (Morais et al., 2003; 2009; Baliza et al., 2012; Araujo et al., 2016), what agrees with the findings of the present work.

In general, black pepper plants cropped under full sun exposure showed the highest photosynthetic rates in early morning, but were as well amongst the plants with greater reductions by midday and in the afternoon, Tsun plants seemed to efficiently control the loss of water by a strong stomatal closure at 12:00 and $16: 00$, likely responding to the decrease in air humidity, and to the increase of air temperature and evaporative demand. However, such strong stomatal closure reduced $\mathrm{C}$-assimilation only in autumn. In the other seasons impairments at biochemical levels might have been involved due to supra-optimal temperatures (especially in spring and summer). Nevertheless, it is noteworthy the resilience of the photosynthetic apparatus in black pepper plants cropped under full sun exposure. In fact, even when the photosynthetic rates were reduced to quite low values (16.00 in all season) it were not observed significant negative impacts as regards the photochemical efficiency of PSII, the estimate of linear electron transport, and the energy driven to photochemistry, pointing for a high functional status of the full sunlight plants.

\section{CONCLUSIONS}

Shaded plant pepper with rubber trees under the conditions studied resulted in improved net photosynthesis rates, stomatal conductance to water vapor, transpiration maintenance, water use efficiency and photochemical preservation in pepper plants. However, the consortium effectiveness was dependent of distance to the rubber tree line, time of the day, Southern or Northern orientation, and season of the year. Shaded intercropped plants displayed some advantage in a few cases (black pepper plants located at $2 \mathrm{~m}$, and $5 \mathrm{~m}$ between rubber trees, southern side) as regards the photosynthetic rate at midday and afternoon, and especially in summer, when compared to pepper plants cultivated in full sunlight condition, That would be likely related to the to the maintenance of somewhat lower temperature and higher relative humidity in the atmosphere close to the black pepper plant implying some advantage for such consortium system to mitigate the possible effects warming.

\section{ACKNOWLEDGMENTS}

The authors would like to thank to Coordenação de Aperfeiçoamento de Pessoal de Nível Superior (Capes Código de Financiamento 001), Universidade Federal do Espírito Santo (UFES) for partial financial support and to Mário Elias Medice, for allowing the use of the experimental area.

\section{REFERENCES}

ARAÚJO, A. V. et al. Microclimate, development and productivity of robusta coffee shaded by rubber trees and at full sun. Revista Ciência Agronômica, 47(4):700-709, 2016.

ARAÚJO, A. V. et al. Microclimatic and vegetative growth in coffee and banana intercrop. Coffee Science, 10(2):214-222, 2015.

ARAUJO, A. V. et al. Microclimate and development of 'Conilon' coffee intercropped with rubber trees. Pesquisa Agropecuária Brasileira, 49(4):872-881, 2014.

BAGHERI, H.; MANAP, M. Y. B. A.; SOLATI, Z. Antioxidant activity of Piper nigrum L. essential oil extracted by supercritical $\mathrm{CO}_{2}$ extraction and hydro-distillation. Talanta, 121(2014):220228, 2014.

BALIZA, D. P. et al. Physiological characteristics and development of coffee plants under different shading levels. Revista Brasileira de Ciências Agrícolas, 7(1):37-43, 2012.

BATISTA-SANTOS, P. et al. Is salt stress tolerance in Casuarina glauca Sieb. ex Spreng. associated with its nitrogen-fixing root-nodule symbiosis? An analysis at the photosynthetic level. Plant Physiology and Biochemistry, 96(2015):97109, 2015.

CAFER, G. et al. Response of red hot pepper plant (Capsicum annuum L.) to the deficit irrigation. Akdeniz Universitesi Ziraat Fakültesi Dergisi, 19(1):131-138, 2006. 
CHAVES, M. M.; FLEXAS, J.; PINHEIRO, C. Photosynthesis under drought and salt stress: Regulation mechanisms from whole plant to cell. Annals of Botany, 103(4):551-560, 2009.

DAI, Y. J. et al. Effects of shade treatments on the photosynthetic capacity, chlorophyll fluorescence, and chlorophyll content of Tetrastigma hemsleyanum Diels et Gilg. Environmental and Experimental Botany, 65(2009):177-182, 2009.

DELANEY, K. J.; WEAVER, D. K.; PETERSON, R. Photosynthesis and yield reductions from wheat stem sawfly (Hymenoptera: Cephidae): Interactions with wheat solidness, water stress, and phosphorus deficiency. Journal of Economic Entomology, 103(2):516-524, 2010.

EMBRAPA-EMPRESA BRASILEIRA DE PESQUISAAGROPECUÁRIA. Sistema brasileiro de classificação de solos. 3.ed. Embrapa, Brasília. 2013. p.353.

FAO. Food and Agriculture of the United Nations. Statistical Databases. 2017. Available in: http://www.fao.org/ statistics/databases/en/. Access in: May 6, 2017.

FENG, X.; PORPORATO, A.; RODRIGUEZ-ITURBE, I. Changes in rainfall seasonality in the tropics. Nature Climate Changes, 3:811-815, 2015.

FERRAZ, T. M. et al. Comparison between single-leaf and wholecanopy gas exchange measurements in papaya (Carica papaya L.) plants. Scientia Horticulturae, 209:73-78, 2016.

FLEXAS, J. et al. Photosyn thesis limitations during water stress acclimation and recovery in the drought-adapted Vitis hybrid Richter-110 (V. berlandierix $\times$ V.rupestris). Journal of Experimental Botany, 60(8-1):2361-2377, 2009.

GHANNOUM, O. et al. Photosynthetic responses of two eucalypts to industrial-age changes in atmospheric $\left[\mathrm{CO}_{2}\right]$ and temperature. Plant,Cell \& Environment, 33:1671-1681, 2010.

GONTIJO, I. et al. Variabilidade e correlação espacial de micronutrientes e matéria orgânica do solo com a produtividade da pimenta do reino. Revista Brasileira de Ciência do Solo, 36:1093-1102, 2012.

HUANG, W.; ZHANG, S. B.; CAO, K. F. Cyclic electron flow plays an important role in photoprotection of tropical trees illuminated at temporal chilling temperature. Plant Cell Physiology, 52(2):297-305, 2011.

HUANG, D.; OU, B.; PRIOR, R. L. The chemistry behind antioxidant capacity assays, Journal of Agricultural and Food Chemistry, 53:1841-1856, 2005.

IPCC. INTERGOVERNMENTAL PANEL ON CLIMATE CHANGE (2014) Working group III. Mitigation of Climate Change. 99p. Available in: <hhttp://report.mitigation2014.org/ drafts/final-draft-postplenary/ipcc_wg3_ar5_final-draft_ postplenary_technical-summary.pdf $>$. Access in: December 7, 2016.

INTERNATIONAL PEPPER COMMUNITY - IPC. Pipper news market review: December 2015. 4p, 2015 (Documento).

KIRSCHBAUM, M. U. F. Does enhanced photosynthesis enhance growth? Lessons learned from $\mathrm{CO}_{2}$ enrichment studies. Plant Physiology, 155:117-124, 2011.

KLUGHAMMER, C.; SCHREIBER, U. Complementary PS II quantum yields calculated from simple fluorescence parameters measured by PAM fluorometry and the Saturation Pulse method. PAM Application Notes, 1:2735, 2008.

KRAMER, D. M. et al. New flux parameters for the determination of QA redox state and excitation fluxes. Photosynthesis Research, 79:209-218, 2004.

$\mathrm{LI}, \mathrm{T}$. et al. Diurnal changes in photosynthesis in Sclerocarya birrea from South Africa and Israel after introduction and acclimatization in Wenshan, Yunnan Province, China. South African Journal of Botany, 100:101-107, 2015.

MARTINS, M. Q. et al. Protectiveresponse mechanisms to heat stress in interaction with high $\left[\mathrm{CO}_{2}\right]$ conditions in Coffea spp. Frontiers in Plant Science, 7:1-18, 2016.

MEDEIRA, C. et al. Cryptogein and capsicein promote defence responses in Quercus suber against phytophthora cinnamomi infection. European Journal of Plant Pathology, 134:145-159, 2012.

MA, C. C. et al. Photosynthesis, transpiration and water use efficiency of Caragana microphylla, C. intermedia and C. korshinskii. Photosynthetica, 42(1):65-70, 2004.

MEGHWAL, M.; GOSWAMI, T. K. Piper nigrum and piperine: An update. Phytotherapy Research, 27:1121-1130, 2013.

MORAIS, H. et al. Shading of coffee plants during floral buds development and its effects on fructification and production. Ciência Rural, 39(2):400-406, 2009.

MORAIS, H. et al. Physiological characteristics and growth of coffee plants grown under shade of pigeon pea and unshaded. Pesquisa Agropecuária Brasileira, 38(10):1131-1137, 2003.

MORANDI, B. et al. Leaf gas exchanges and water relations affect the daily patterns of fruit growth and vascular flows in Abbé Fétel pear (Pyrus Communis L.). trees. Scientia Horticulturae, 178: 106-113, 2014. 
MONROE, P. H. M.; GAMA-RODRIGUES, E. F.; GAMA-RODRIGUES, A. C. Soil carbon stocks and origin under different cacao agroforestry systems in Southern Bahia, Brasil. Agriculture, Ecossystems and Environment, 221:99-108, 2016.

OLIOSI, G. et al. Microclimate and development of Coffea canephora cv. Conilon under different shading levels promoted by Australian cedar (Toona ciliata M. Roem. var. Australis). Australian Journal of Crop Science, 10(4):528538, 2016.

PALMER, J. The future role of crop physiologists. A personal view. Acta Horticulturae, 1058: 209-219, 2014.

PARTELLI, F. L. Nutrition of black pepper (Piper nigrum L.) - A Brazilian experience. Journal of Spices and Aromatic Crops, 18:73-83, 2009.

PEZZOPANE, J. R. M. et al. Microclimatic alterations in a conilon coffee crop grown shaded by macadamia nut tree. Ciência Rural, 40(6):1257-1263, 2010.

PINHEIRO, C.; CHAVES, M. M. Photosynthesis and drought: Can we make metabolic connections from available data? Journal of Experimental Botany, 62(3-1):869-882, 2011.

REDDY, A. R.; RASINENI, G. K.; RAGHAVENDRA, A. S. The impact of global elevated $\mathrm{CO}_{2}$ concentration on photosynthesis and plant productivity. Current Science, 99:46-57, 2010.

RODRIGUES, W. P. et al. Long-term elevated air $\left[\mathrm{CO}_{2}\right]$ strengthens photosynthetic functioning and mitigates the impact of supra-optimal temperatures in tropical Coffea arabica and C. canephora species. Global Change Biology, 22:415-431, 2016.

RYLSKI, I.; SPIGELMAN, M. Efects of diferent diurnal temperature combinations on fruit set of sweet pepper. Scientia Horticulturae, 17:101-106, 1982.

SANTOS, C. A. F. et al. Perspectives on the potential impacts of climate changes on coffee plant and bean quality. Emirates Journal of Food and Agriculture, 27(2):152163,2015

SCHOCK, A. A. et al. Growth and photosynthesis of Physic nut grown under different light conditions. Revista Brasileira de Engenharia Agrícola e Ambiental, 18(1):3-9, 2014.
SHARKEY, T. D.; RASCHKE, K. Separation and measurement of direct and indirect effects of light on stomata. Plant Physiology, 68:33-40, 1981

SCHREIBER, U. Pulse-Amplitude-Modulation (PAM) fluorometry and saturation pulse method: An overview. In: Papageorgiou, G. C.; Govindjee. (Eds.) Chlorophyll a Fluorescence: A Signature of Photosynthesis, Dordrecht: Springer, p.279319, 2004.

SOUZA, R. P. et al. Photosynthetic gas exchange, chlorophyll fluorescence and some associated metabolic changes in cowpea (Vigna unguiculata) during water stress and recovery. Environmental and Experimental Botany, 51:45-56, 2004.

SHOWEMIMO, F. A.; OLAREWAJU, J. D. Drought tolerance indices in sweet pepper (Capsicum annum L.). International Journal of Plant Breeding and Genetics, 1(1):29-33, 2007.

STIRBET, A.; GOVINDJEE. On the relation between the Kautsky effect (chlorophyll a fluorescence induction) and Photosystem II: Basics and applications of the OJIP fluorescence transient. Journal of Photochemistry and Photobiology B: Biology, 104:236-257, 2011.

SUI, X. et al. Effect of low light on the characteristics of photosynthesis and chlorophyll a fluorescence during leaf development of sweet pepper. Journal of Integrative Agriculture, 11:1633-1643, 2012.

ZHU, J. J. et al. Leaf gas exchange, chlorophyll fluorescence, and fruit yield in hot pepper (Capsicum annuum L.) grown under different shade and soil moisture during the fruit growth stage. Journal of Integrative Agriculture, 11:927937, 2012.

WANG, H. et al. The responses of photosynthetic capacity, chlorophyll fluorescence and chlorophyll content of nectarine (Prunus persica var. Nectarina Maxim) to greenhouse and field grown conditions. Scientia Horticulturae, 112:66-72, 2007.

WU, B. J. et al. Effects of stomatal development on stomatal conductance and on stomatal limitation of photosynthesis in Syringa oblata and Euonymus japonicus Thunb. Plant Science, 229:23-31, 2014. 